\title{
Instrumentalization of Law in the Context of Memory Policies in Central and Eastern Europe after $1989^{2}$
}

\section{Introduction}

The term instrumentalization of law seems to be an interesting concept, with the potential to be located somewhere in between the rule of law, which is "lauded by international agencies, pressed upon conflictual, post-conflict and 'transitional' societies, and of course talked up by politicians and lawyers, particularly judges, all over the world" 3 and its opposite, the rule by law. In some of their texts, researchers from the common law culture, gravitating towards the concept of liberal constitutionalism ${ }^{4}-$ including Martin Krygier or Joseph Raz - seem to perceive the socio-legal, constitutional reality, as a black-and-white world. At first glance, the existence of only two models seems possible in such a system: either the rule of law as a system of protection of individual rights and freedoms, or the rule by law, where several societies exist under the never-ending threat of political power's arbitrary judgements. Such a division is useful in academic discussion; it creates clear borderlines and helps in the formulation of several checklists helpful for the evaluation of rule of law in individual states. Nevertheless, the experience of everyday functioning of the political system, especially in the states where the checks and balances culture - typical for both liberal and republican constitutionalism - is still insufficiently developed (among others in Central and Eastern Europe [CEE] in the transitional period), shows the possible existence of indirect, in-between forms of legal policy as well. The instrumentalization of law, especially its narrow perspective, seems to be an interesting concept to fill such a gap and better understand the character and the vision of all systems affected by transitional complexity.

\footnotetext{
ORCID number: 0000-0003-2669-7822. E-mail: filip.cyunczyk@gmail.com

2 The paper was written as a result of realization of the research project number 2016/23/D/HS5/01826 Experience and common sense. Aesthetic foundation of validation in contemporary philosophy of law financed by Polish National Science Centre (Polish: Narodowe Centrum Nauki).

3 M. Krygier, Rule of Law, in: M. Rosenfeld, A. Sajo (eds.), The Oxford Handbook of Comparative Constitutional Law, Oxford 2012, p. 233.

4 See: M. Loughlin, What is constitutionalization?, in: P. Drobner, M. Loughlin (eds.), The Twilight of Constitutionalism?, Oxford 2010, pp. 57-58.
} 
For this reason, the central idea of this paper is to present the concept of the instrumentalization of law in a narrow sense formulated by a Polish legal philosopher Włodzimierz Gromski ${ }^{5}$. My primary aim is to show his achievements in reference to a particular research problem, the so-called memory policies implemented in Central and Eastern European political reality during the democratic transitions away from communism. There are two reasons behind the choice of such a case study. Firstly, while the decision to apply the memory narratives, which create collective societal memories, inside a legal text is an autonomous decision of a particular political regime, the fact that these narratives are mixed with liberal democratic constitutions adopted all over CEE after the collapse of communism is a specific feature of transitional constitutionalism in the region. Secondly, the adoption of liberal democratic constitutions by CEE postcommunist countries was determined not by a deep belief in the effectiveness of such a system, but rather by the strategic goal of all these states: integration with the political structures of the so-called Western world. Processes stimulated by the need to "return to the West" were the main determinants of the paths and directions of Central and Eastern European constitutionalization. The side effect was partial compliance of the "new" European Union Member States' legal systems with external mechanisms of control coming from the supranational constitutionalization (mainly with EU treaties). However, these mechanisms are presented as checklists for upholding fundamental values of the EU (supranational) institutional reality, including the rule of law. Thus, the creation of internal identities by various political communities is still left entirely to the Member States. Direct and uncontrolled influence on the creation of collective societal memories (including their impact on the perception of contemporary reality) is one of the "privileges" left to nation states.

In the first part of the paper, I present the communitarian elements of liberal democratic constitutions, which constituted new political communities in CEE after the collapse of communism. Next, I describe Gromski's concept of instrumentalization of law in a narrow sense. Finally, in the third part, I present case studies of several CEE political regimes which have used law to petrify their memory policies. In other words, these states created a strict (or at least symbolic) legal framework of societal remembrance. The link between these case studies and the concept of instrumentalization of law creates a space for more in-depth studies of states' institutional policies. Thus, it offers new perspectives for the formulation of the checklists essential for, among others, the evaluation of adherence to the rule of law all over the "new" European Union.

\section{Constitutionalisation of CEE political communities after 1989}

The collapse of the communism in Central and Eastern Europe led to the reconstruction of political communities. A community's self-organization is embodied in a new constitution or another form of a fundamental law. In case of CEE post-communist states, between 1989 and 2011, all new constitutional acts and all important amendments of the communist constitutions were rooted in the liberal-democratic tradition. The motives for the creation of a new political community are presented in a specific part of the instrument - the preamble. As Jiri Přibán pointed out, preambles

\footnotetext{
See: W. Gromski, Autonomia i instrumentalny charakter prawa [Eng. Autonomy and the Instrumental Character of Law], Wrocław 2000.

6 "New" here means those who joined the EU during the 2004/2007 enlargement.
} 
are emanations of "the self-obligating will of the sovereign people (...) ceremoniously codified" ". Moreover "the preambles to acts of constitutional law then often may sound like a summary and synthesis of historical wisdom" CEE constitution-makers formulated the preambles to their constitutions: references to the past are present in all constitutional acts in the region. Moreover, the tendency to endow these acts with such an element, if it was lacking at first, is more than visible.

The presence of the constitutional preamble is an autonomous decision of each national constitution-maker. Strong links between those past events which constitute the present political reality and the political communities established by several constitutional acts are visible in Portuguese and South African transitional constitutions. By contrast, references to the past are excluded from German and Spanish constitutions. In the case of Israel, the role of a preamble is played by the Declaration of Independence, in which the narrative is logically and ideologically selected and formatted to justify the creation of the state. It is because the Jewish history from the beginning of the diaspora and until the creation of Israel in 1948 was determined by Zionist thinking about the past. Generally, the most visible conflict of values concerns the relations between ethnos and demos in particular political communities. One can argue that the decision to use the past for constitutional identity formation depends on its usefulness for the present (and comes from the particular historical experiences) ${ }^{9}$.

Since 2014, elements of the collective identity, rooted in the past, have been present in all CEE constitutions. In Romania and Latvia they were added through constitutional amendment, and in Hungary through the acceptance of the new Fundamental Law of Hungary by its parliament. From the adoption, references to the past have also been present in basic laws of Estonia, Lithuania, Poland, Czechia, and Slovakia. Ukrainian legislators have used past narratives in the preamble to the act that already has binding force (the constitution was re-established after the Revolution of Dignity in 2013-2014). In the following section, I focus on the three examples - Hungary, Latvia and Romania ${ }^{10}$ - as they clearly show the correspondence between the law, its subjects, and the legal tools used to achieve political goals. In each case, political motivation for amending the constitution can be identified.

The Fundamental Law of Hungary of 2011 is an act establishing a new political community created in an illiberal manner, which includes active communitarian elements. The difference between recent liberal constitutionalism and "Hungarian-Orbanian" illiberalism begins with different semantics. The name of the instrument is "The Fundamental Law" instead of "The Constitution". The name of the state does not contain any determinant of its character (such as "republic"): Hungary is Hungary - and nothing else. Finally, the preamble is named "National Avowal", which could suggest a deep metaphysical relation between the Hungary's statehood and its citizens (subjects?). Using a religious analogy, one can say that here the catalogue of beliefs is

\footnotetext{
J. Přibáň, Legal Symbolism: On Law, Time and European Identity, London-New York 2007, p. 5.

J. Přibáň, Legal Symbolism..., p. 60.

See: M. Rosenfeld, The Identity of the Constitutional Subject. Selfhood, Citizenship, Culture and Community, London -New York 2010.

10 See: The Fundamental Law of Hungary of 25 April 2011, amended version available in English at: https://www. kormany.hu/download/f/3e/61000/TheFundamentalLawofHungary_20180629_FIN.pdf, accessed on: 4 May 2020; The Constitution of the Republic of Latvia of 15 February 1922, amended version available in English at: https:// likumi.lv/ta/en/id/57980-the-constitution-of-the-republic-of-latvia, accessed on: 4 May 2020; Law No. $429 / 2003$ on the Revision of the Constitution of Romania (Official Gazette No. 669 of 22 Sep. 2003), available in English at: http:// www.cdep.ro/pdfs/reviz_constitutie_en.pdf, accessed on: 4 May 2020.
} 
determined by the political forces that adopted the law, and the citizen is given a clear vision of how he/she should recognize the past and the present. The state power suggests that the "real Hungarians" should approve of the presented elements that tend to constitute them as Hungarians ${ }^{11}$. Otherwise, they can find themselves outside of the community framework - just as in Christianity where the faith has to be declared before receiving the Holy Eucharist. The text of the Credo is formulated and has to be accepted without any objection, or else the believer cannot take part in the holiest element of the liturgy.

The Latvian case is more complicated. The first time narratives of the past appeared as an argument for legislative action when Latvia was leaving the USSR. The 1990 Declaration of the Supreme Soviet of the Latvian SSR on the Renewal of the Independence of the Republic of Latvia ${ }^{12}$ employed arguments mainly determined by the collective memory of Latvians. The interpretation of the events of Spring 1940 was typical for their national co-remembering. The authors of the 1990 Declaration of Independence described the motives for restoring Latvia's independence. The interpretation of the events of Spring 1940 was typical for their national co-remembering. The main legal argument was based on the illegality of the parliamentary elections in 1940 and the parliament's decision on accession to the USSR. In effect, the members of the Supreme Soviet of the Latvian SSR recognised themselves as being bound by the duty to restore the proper legal status of Latvia - not only de jure but also de facto. What is interesting is that the Soviet supremacy over Latvia ended because of the use of Soviet legal philosophy of the state political order. The Supreme Soviet of Latvia was able to declare itself as the only authority in the Latvian territory in accordance with the Soviet doctrine of democratic centralism, the essence of which was control of the supreme soviets over different branches of power both in the republics and on the federal level.

The second time Latvian legislators used memory narratives was in 2014. The decision to start legislative work on the constitutional amendment containing the preamble was a direct effect of the so-called "language referendum" of 2012, lost by political

11 The National Avowal can be divided into three general parts: a) elements of social life which are the source of Hungarian pride; b) elements (including events from the past) which Hungarian political community recognizes; or c) ones which it does not recognize, as they are generally inconsistent with the elements from point b), and are therefore contrary to the objects and event constituting the political community of Hungary. In the first part, Hungarians are said to be proud that: "king Saint Stephen built the Hungarian State on solid ground and made our country a part of Christian Europe one thousand years ago"; of "forebears who fought for the survival, freedom and independence of our country"; and that the "nation has over the centuries defended Europe in a series of struggles and enriched Europe's common values with its talent and diligence". The element of recognition appears when the preamble makes references to, inter alia, Christian values ("We recognize the role of Christianity in preserving nationhood"), the "historical constitution", and "the Holy Crown" ("We honour the achievements of our historic constitution and we honour the Holy Crown, which embodies the constitutional continuity of Hungary's statehood and the unity of the nation"). The last perspective - the lack of recognition - is strictly connected with the past: "We do not recognize the suspension of our historic constitution due to foreign occupations. We deny any statute of limitations for the inhuman crimes committed against the Hungarian nation and its citizens under the national socialist and the communist dictatorship"; "We do not recognize the communist constitution of 1949, since it was the basis for tyrannical rule; we therefore proclaim it to be invalid"; "We date the restoration of our country's self-determination, lost on the nineteenth day of March 1944, from the second day of May 1990, when the first freely elected organ of popular representation was formed. We shall consider this date to be the beginning of our country's new democracy and constitutional order". See: Fundamental Law of Hungary of 25 April 2011, National Avowal.

12 See: Declaration of the Supreme Soviet of the Latvian SSR on the Renewal of the Independence of the Republic of Latvia, in: T. Jundza (ed.), 4. maijs, Rakstu, atminu un dokumentu krajums per Neatkaribas deklaracju [Eng. May 4, Collection of Articles, Memoirs and Documents Concerning the Declaration of Independence], Riga 2000, pp. 355-357. 
groups which represented part of the Russian speaking community of Latvia ${ }^{13}$. The amendment presents the historical sources of Latvian statehood and its orientation towards the Latvian State of Latvian people, which statehood is constituted by the people's past experiences and suffering. According to the legislative branch, the fundamental traditions which determine societal understanding of the state's character belong to Livs and Latvians. It is important to emphasize that the adoption of the preamble was not an act of reconstruction of the political community: it was merely a confirmation of the national perspective adopted in the 1990 Declaration of Independence.

Among the post-communist states that joined the EU and NATO between 1999 and 2007 Romania is probably the most complicated one from the political point of view. It is not my intention to analyse all political and legal processes that appeared there between the December 1989 Revolution and Romania's accession into the political structures of the Western World. Still, it is beyond discussion that some social processes connected with the democratic transition appeared there with a delay. Until 2003 Romania was one of three CEE countries (apart from Hungary and Latvia) whose constitution did not include historical narratives. In 2003 the situation changed: instead of adding the preamble, the constitutional amendment reformulated Article 1(3) of the Romanian Constitution $^{14}$. According to the amended provision, Romania is "a democratic and social state, governed by the rule of law, in which human dignity, the citizens' rights and freedoms, the free development of human personality, justice and political pluralism represent supreme values, in the spirit of the democratic traditions of the Romanian people and the ideals of the Revolution of December 1989, and shall be guaranteed" 15 . The essence of the amendment was the addition of an undefined concept of "the spirit of the democratic traditions of the Romanian people and the ideals of the Revolution of December 1989". Interestingly, at that time both the president and the parliamentary majority belonged to the post-communist social democratic party.

As already mentioned, apart from the examples described above, references to the past are also present in other CEE constitutions. In the Polish 1997 Constitution $^{16}$ one can find, inter alia, references to the best traditions of the $1^{\text {st }}$ and $2^{\text {nd }}$ Polish Republics and to the bitter experiences of totalitarian and authoritarian systems. The Czech Constitution of $1992^{17}$ contains references to the Crown of Bohemia and Czechoslovak statehood. In the Lithuanian Fundamental Law ${ }^{18}$, one can find references to the State of Lithuania, and the suffering of Lithuanians who strove to protect their ethnic identity.

Some Polish scholars have discussed the use of historical and memory narratives in legal acts and the trend of making references to the past during the transitional period.

13 See: I. Durviete, U. Ozolins, The Latvian referendum on Russian as a second state language, February 2012, "Language Problems and Language Planning" 2016/2, pp. 121-145.

14 For more about the role of the memory in Romanian political reality see e.g.: C. Cercel, Law out of Bounds: Legal Picnolepsy, Intelectual Austerity and Romanian Legal Past, in: R. Mańko, C. Cercel, A. Sulikowski (eds.), Law and Critique in Central Europe. Questioning the Past, Resisting the Present, Oxford 2016, pp. 44-65.

15 Article 1(3) of the Constitution of Romania of 21 November 1991, available in English at: http://www.cdep.ro/pls/ dic/site2015.page?id=371\&idl=2\&par1=1, accessed on: 4 May 2020 (emphasis added).

16 The Constitution of the Republic of Poland of 2 April 1997 (Polish title: Konstytucja Rzeczypospolitej Polskiej z 2.04.1997 r., Dz. U. Nr 78, poz. 483 ze zm.).

17 The Constitution of the Czech Republic No. 1/1993 Coll., adopted on 16 December 1992 (Czech title: Ústava České republiky ze dne 16. prosince 1992 č.: 1/1993).

18 Constitution of the Republic of Lithuania, adopted by citizens of the Republic of Lithuania in the Referendum of 25 October 1992 (Lithuanian title: Lietuvos Respublikos Konstitucija, Lietuvos Respublikos piliečių priimta $1992 \mathrm{~m}$. spalio 25 d. referendume). 
My intention is to present now some general ideas on why lawmakers may decide to articulate such links with the past.

Anna Młynarska-Sobaczewska believes that the use of narrative of memories in the CEE constitutions is an attempt to secure trust in the framers of the constitution and in the political powers established on the basis of auto-legitimacy ${ }^{19}$. She also argues that if the tradition of statehood is weak, the references tend to relate to the distant past. A perfect example of such a tendency are the references to the Great Moravian State included in the preamble to the Slovak constitution ${ }^{20}$.

According to political scientists Joanna Marszałek-Kawa, Anna Ratke-Majewska, and Patryk Wawrzyński, the transition could be fulfilled just by presenting a vision of the future and without recourse to the narratives of memory and references to the past. However, "the reconstruction of the community vision has to be rooted in the presentation of the common core, traditions and the experiences constituting it"21.

Finally, Dariusz Gawin explores how the decision to seek legitimacy in the nation's past can be compatible with contemporary societal reality. He points out that:

contemporary capitalist and democratic societies tend to seek the legitimacy of the political system's power in the legal and institutional sphere. In this context, the spheres of memory and power should be separated. Memory of the past has been a source of power legitimacy in traditional societies, where the institutions were legitimized by reference to everlasting rules and norms - everlasting because their historical sources disappear in the shadows of the past and they can be reproduced only through myths, symbols and beliefs ${ }^{22}$.

Each of these three positions includes elements crucial for my analysis. Even though each of the quotes presents a different perspective and a different approach, in all of them a fundamental political interest is visible: the need for recognition of power by society. Thus, their common core is the need of the political factor to be positively recognised by the society as being legitimate for holding power in the name of the people, by the people, for the people.

\section{Instrumentalization of law}

The instrumentalization of law can be understood in several ways. In a broad sense, the law is treated as a "tool or means created for the achievement of an external goal (of law)"23. This approach appears in two forms: the reductionist one and the non-reductionist one. According to the former, the law has an instrumental character, because its norms and regulations are interpreted as instrumental or purposive directives. The latter approach treats the law as a system where the legal norms and institutions could be

19 A. Młynarska-Sobaczewska, Normatywizacja tożsamości zbiorowej w preambutach do konstytucji państw postkomunistycznych [Eng. Normative-making of collective identity in the preambles to the constitutions of the postcommunist European states], "Filozofia Publiczna i Edukacja Demokratyczna" 2013/2, p. 111.

20 Constitution of the Slovak Republic of 1992 (460/1992 Coll.). (Slovak title: Ústavný zákon č. 460/1992 Zb., Ústava Slovenskej Republiky).

21 J. Marszałek-Kawa, A. Ratke-Majewska, P. Wawrzyński, Polityka pamięci i ksztattowanie tożsamości politycznej w czasie tranzycji postautorytarnej. Tom 2: Analiza porównawcza [Eng. The Politics of Memory and the Formation of Identity in Post-Authoritarian Transition, Volume 2: Comparative Analysis], Warszawa 2016, p. 111.

22 D. Gawin, Legitymizacja i pamięć [Eng. Legitimacy and Memory], in: A. Rychard, H. Domański (eds.), Legitymizacja w Polsce. Nieustajacy kryzys w zmieniajacych się warunkach? [Eng. Legitimacy in Poland. Continuing Crisis in Changing Conditions?], Warszawa 2010, p. 17.

23 W. Gromski, Akty instrumentalizacji prawa i ich granice [Eng. Acts of Instrumentalization of Law and Their Limits], "Przegląd Prawa i Administracji" Wrocław 2018/114, p. 98. 
(or are) used "by the individuals and bodies units responsible for the law's creation and execution, or the other addresses of the law, for realization of various goals (especially for the protection of the individual and group interests)" ${ }^{24}$. The instrumentalization of law in a broad sense suggests that any real alternative to this phenomenon is impossible, as the law always has an instrumental character.

The instrumentalization of law in a narrow sense - which perspective is crucial for this paper - means that the law is understood not as a mechanism of achieving goals, but simply as a tool. In this narrow sense, the term "instrumentalization of law" is used to indicate that the law is used for a particular purpose, in contrast to the broad meaning which investigates the whole legal system as potentially instrumentalised by various individuals and bodies that possess powers of influence. Even if we assume that the instrumental character of law (i.e. the fact that the law is a tool used to affect the society) is essential for understanding different processes that arise between law and society, this does not mean that we can talk of instrumentalization of law in a narrow sense. The use of that term is justified when, within a legal system, subjects of law act according to their defined intentions, using law as their means. In a similar vein, Stawomira Wronkowska describes the instrumentalization of law as "an action of a concrete subject whose intention is to achieve a strategic goal" 25 , which seems to be consistent with Gromski's view. Wronkowska also distinguishes a so-called objectionable instrumentalization. This unique form of instrumentalization of law - important for my analysis - appears when "the law is transformed (without its official change) so it can be used to achieve goals that were unacceptable in the legal system before"26. In other words, according to Wronkowska, the instrumental character of law is not a threat to the proper functioning of the legal order, as long as all the elements of the legal and institutional system function within a legally and socially accepted framework.

The instrumentalization of law in a narrow sense, including the objectionable instrumentalization, creates the need for setting limits of acceptable instrumentalization. It is crucial from the CEE perspective, where a general shift in these matters occurred in the early 1990s. As Gromski points out, a general reformulation of the understanding of the role of law co-occurred with a change in the meaning of its instrumentalization ${ }^{27}$ during the period of CEE democratic transitions. In other words, for the first time after since the interwar period ${ }^{28}$, after the fall of communism the autonomous character of law and the rule of law were fully recognized in the region. The autonomy of the legal system is crucial to the idea of the rule of law.

\section{A few examples of memory policies and attempts at their legal control}

I am aware that an in-depth, descriptive presentation of all examples of states' legal activities in the field of societal collective memories demands a much more extensive paper (or even a monograph). Nevertheless, in this section, I intend to present some examples of how law was used by political actors in the region. I chose three legislative

24 W. Gromski, Akty instrumentalizacji..., p. 98.

${ }_{25}$ S. Wronkowska, Kilka tez o instrumentalizacji prawa i ochronie przed nia [Eng. Some Theses Concerning the Instrumentalisation of Law and Protection Against It], "Przegląd Prawa i Administracji" 2017/110, p. 107.

${ }_{26}$ S. Wronkowska, Kilka tez..., p. 110.

27 See: W. Gromski, Akty instrumentalizacji...

${ }_{28}$ Between 1918 and 1939 formally liberal political systems functioned in the CEE. All of them, with an exception of Czechoslovakia, ended up with some form of coup d'état. 
actions which in my opinion are the most controversial, and where the potential for instrumentalization of law in a narrow sense, or even its objectionable instrumentalization, is high.

In Poland, first attempts to change the 1998 statute establishing the Polish Institute of National Remembrance (Polish: Instytut Pamięci Narodowej, IPN) appeared just after the 2015 election when the Law and Justice party won a parliamentary majority. The main motives presented by the authors of the amendment were: protection Poles' reputation as victims, and preserving the historical truth about the $20^{\text {th }}$ century events and experiences of CEE totalitarian regimes. Such arguments were a reaction to public declarations of politicians - including Barack Obama - and of the media, using the term "Polish death camps", which in the opinion of many Poles suggested their co-responsibility for the Holocaust. As a result, the amendment passed by the Polish parliament on 14 February 2018 added two new criminal provisions: Articles 55a and 55b. Article 55a provided the possibility of prosecution of a person "who publicly and against the facts" suggests Polish responsibility for the crimes committed by the Nazi German regime, or for other war crimes, crimes against peace or humanity; it also became illegal to grossly diminish the responsibility of true perpetrators of these crimes. In case of intentional activity, the highest sanction was three years of imprisonment ${ }^{29}$. Such a formulation of criminal norms was criticised by politicians and lawyers alike. After international protests - coming mainly from Israel, but also from Ukraine - the controversial provisions were repealed by another amendment adopted in June (!) 2018.

In the same February 2018 amendment, Polish legislators decided to extend the catalogue of crimes covered by the 1998 Institute of National Remembrance Act, to include crimes conducted by Ukrainian nationalists and Ukrainian formations collaborating with Nazi Germany in the regions of Volhynia and Eastern Małopolska. These terms recognized and legally defined the ethnic cleansing of Polish civilians before, during and after II World War (1925-1950) by Ukrainian military and paramilitary formations. The extension of IPN powers - which previously concentrated on the periods of Nazi and Soviet occupation, and on Polish People's Republic - to this part of history too resulted in a diplomatic crisis The terms "Ukrainian Nationalists" and "Eastern Małopolska" were excluded from the statute by a judgment of the Polish constitutional court ${ }^{30}$.

The Ukrainian Institute for National Remembrance is an interesting example of a direct impact of law (and a political decision behind it) on the sphere of collective memory. According to the Decision of the Cabinet of Ministers of Ukraine, the Institute is responsible for promoting and carrying out the Ukrainian state's memory policies, and is located in the state legal system as a "centralized authority of the executive power" (Section 1) ${ }^{31}$. The legal framework in which the Institute functions shows its direct dependence on state executive powers: the Institute bodies are supervised by and report to the Prime Minister and the Minister of Culture. Its mandate, as in the case of the Polish IPN, is determined by law. In other words, both institutes function

29 Articles 55a and 55b of the Act of 18 December 1998 on the Institute of National Remembrance - Commission for the Prosecution of Crimes against the Polish Nation (Polish title: Ustawa z dnia 18 grudnia 1998 r. o Instytucie Pamięci Narodowej - Komisji Ścigania Zbrodni przeciwko Narodowi Polskiemu, tekst jedn.: Dz. U. z 2016 r. poz. 1575 ze zm.).

30 Judgment of the Constitutional Tribunal of 17 January 2019 (K 1/18), OTK-A 2019, item 6. Summary available in English at: https://tinyurl.com/CTK12018, accessed on: 4 May 2020.

31 Decision on the Creation of the Ukrainian Institute of the National Remembrance (Ukrainian title: ПОСТАНОВA про Український інститут національної пам'яті), 12 October 2014, available at: https://zakon2.rada.gov.ua/laws/ show/684-2014-\%D0\%BF\#n11, accessed on: 4 May 2020. 
in a strict legal framework defined by the legislative (Poland) or executive (Ukraine) power. The law also determines the areas of their activities and the forms of memory preservation they apply. Thus, the law describes precisely what the Ukrainian Institute should do to achieve the objectives of the State within the collective memory field.

The law also lists particular past events which, according to legislators, are fundamental for Ukrainian historical policies. These include: 1) the attempts to create an independent Ukrainian state in the years 1917-1921, 2) pre- and past-World War II famines, 3) anti-Ukrainian repressions during the Soviet period and even 4) co-memorization of the contemporary "anti-terrorist operation" in Eastern Ukraine. Moreover, legislators have identified an extraordinary moment, which possesses a unique name coming from the Ukrainian language: Holodomor. This name belongs only to one particular moment, i.e. the 1932-1933 Great Famine, and can be translated as a "famine-genocide" or as "extermination by starvation".

The political dependency of the Ukrainian Institute of National Remembrance is beyond doubt. The entire decision establishing the Institute is an instruction for its formation and an emanation of the political vision of its functioning as a central state institution. Both the way the Institute bodies are appointed and the sources of its financing show not indirect, but clearly direct dependency on the other branches of political power, mainly the executive ${ }^{32}$.

The last example comes from an area located far from Central and Eastern Europe - the Basque Country. Nevertheless, this case study shows some legislative tendencies interesting from the CEE perspective. Firstly, the legislation related to the past is used for political reasons. Secondly, as in the CEE, legislators show an ambition to become memory agents, even if they use slightly different argumentation and legal reasoning. In effect, the law is a tool for achieving political goals in the Basque Country as well.

The autonomous community of the Basque Country has classified its legislative initiative in the field of memory as part of the welfare and social security system. Such a choice comes from its powers granted in the Statute on the Autonomy: Spanish autonomous regions have no right to organize their memory policies. Nevertheless, the autonomous Basque legislators have recognized the right to memory as part of society's overall well-being. The first sentence of the Act on the Creation of Institute of Memory, Coexistence, and Human Rights presents such argumentation: "Article 9 of the Statute on the Autonomy establishes the fundamental mission that should guide the performance of Basque public authorities, including the guarantee of the proper exercise of the fundamental citizens' rights and duties". ${ }^{33}$ In consequence "management of the democratic memory is one of the factors directly linked to the restitution and promotion of values such as freedom, equality and human dignity" ${ }^{34}$, and thus falls with the powers of the autonomous government. The government of the Basque Country feels a responsibility to become a memory agent because its society experienced at least four traumatic events: civil war, Franco's dictatorship, ETA terrorism, and illegal

\footnotetext{
32 For the analysis of other acts affecting public commemoration in Ukraine, with a particular reference to the decommunisation phenomenon, see e.g.: L. Klymenko, Cutting the Umbilical Cord: The Narrative of the National Past and Future in Ukrainian De-communization Policy, in: U. Belavusau, A. Gliszczyńska (eds.), Law and Memory. Towards Legal Governance of History, Cambridge 2017, pp. 310-328.

33 Act 4/2014 of 27 of November on the Creation of Institute of Memory, Coexistence and Human Rights (Spanish title: Ley 4/2014, de 27 noviembre, de creation del Instituto de la Memoria, la Convivencia y los Derechos Humanos), available at: https://www.boe.es/eli/es-pv/1/2014/11/27/4, accessed on: 4 May 2020.

34 Act 4/2014 of 27 of November on the Creation of Institute of Memory, Coexistence and Human Rights.
} 
anti-terrorist actions. Therefore, as a socially responsible government, it feels the obligation to form and reformulate the collective memories in the Basque Country with the hope that it will help in societal reconciliation and promotion of universal values, including human rights. Thus, the explanatory part of the act - presenting motives for adoption of the statute - portrays the Basque autonomous government as a socially responsible manager that is aware of the specific problems arising in the area under its protection.

From the CEE regional perspective, the initiative of the Basque government shows two important elements. Firstly, the interpretation of at least three out of four events presented by the legislators is different in Spanish and Basque societies. Collective memories formed during the last decades provide different narratives. In consequence, the autonomous Basque Country in fact promotes a vision of the past at odds with the one present in other parts of Spain, or even contrary to some elements of "central" memory narratives. Spanish regionalism is unusual and extraordinarily broad in comparison with Central and Eastern Europe; nevertheless, similar conflicts are visible in the Baltic States, where the conflicts of memory appear between Lithuanians and Poles (in the Vilnius region), and between the Russian population and Latvians or Estonians. Secondly, even a quick glimpse at the Basque statute's normative part shows an active involvement of the autonomous government of the Basque Country, which functions according to the powers delegated by central institutions from Madrid. The question is do we deal with the conflict of power? Even if the Basque government's line of reasoning regarding the collective memory as part of welfare is right, the creation of conflicting memory narratives by the different elements of power is still an undeniable fact.

The case studies presented above allow us to distinguish three elements crucial for applying Gromski's theory of instrumentalization of law in a narrow sense: law, subjects (executors) of law, and the political goal that they intend to achieve.

\section{Conclusions}

The main goal of the paper was to conduct case studies of CEE memory policies introduced after the fall of communism and to present them as an interesting field for examining the instrumentalization of law.

Polish-British scholar Barbara Misztal has divided studies on the collective memory into three general perspectives: "inventors of the tradition", popular memory, and the discursive-dynamic approach ${ }^{35}$. For this paper, the first and the third perspectives are crucial. The discursive-dynamic perspective shows that the formation of collective memories is an on-going and never-ending process. Central and Eastern European states are still trying to play an active role in the development of such a societal commemorating, which brings them closer to the "inventors of the tradition" perspective. The cases described above show the use of the law by several states (and other political actors) to protect their influence on collective memories. The attempts to use law to petrify the societal co-remembering framework are emblematic for the "third wave of constitutions" ${ }^{\prime 36}$. Moreover, even where the constitutions were not provided with

See: B. Misztal, Theories of Social Remembering, Glasgow 2003.

36 See: C. Thornihill, A Sociology of Constitutions. Constitutions and State Legitimacy in Historical-Sociological Perspective, Cambridge 2017, p. 355. 
memory narratives, the trend of implementing such narratives into legal texts (Romania, Hungary, Latvia) shows their role in the reconstruction of societies.

The concept of instrumentalization of law in correlation with memory studies appears to be helpful for examining the relations between law and society in the conditions of liberal constitutional democracy. I am aware that this concept has some weak points. The term "instrumentalization of law" is ambiguous and its variables are still not fully defined. The same can be said about the objectionable instrumentalization. However, its potential is hidden in the applicability of this concept to the socio-legal reality of transitional CEE countries.

As I mentioned in the introduction, the opposing concepts of the rule of law and the rule by law are clear. Problems appear when mechanisms strengthening the rule of law are transplanted into a system where the understanding of the rules, institutions, and procedures is still affected by a different system (a non-democratic one). In such a case, we deal with a hybrid system. In such reality, the concept of instrumentalization of law can be used to assess the quality of functioning of the political system. If adherence to the rule of law and the rule by law is under external supervision, as in the case of the EU supranational legal system, corrective mechanisms can be used and the problem of instrumentalization of law is not so clear and visible. The situation changes when law is used to achieve political goals in the areas still reserved for the nation state, like collective memory and national remembrance. In my opinion, these are the perfect fields for the examining theoretical concept of instrumentalization of law.

\title{
Instrumentalization of Law in the Context of Memory Policies in Central and Eastern Europe after 1989
}

\begin{abstract}
The main goal of the article is to conduct case studies of CEE memory policies introduced after the fall of communism and to present them as an interesting field for examining the instrumentalization of law. The primary research question is: Do several case studies of several memory policies implemented in post-communist states help to examine the theoretical concept of the instrumentalization of law? In this paper, I intend to show the hidden potential of such studies. I present some of the specific elements of new constitutionalization attempts in CEE, which included narratives of memory in several constitutions in the region. I also show their relation to the concept of instrumentalization of law. Finally, I describe some political acts of instrumentalization of law in the field of collective memory.
\end{abstract}

Keywords: instrumentalization of law, memory policies, collective memory, legal petrification of the past 


\section{BIBLIOGRAFIA / REFERENCES:}

Cercel, C. (2016). Law out of bounds: Legal Picnolepsy, Intelectual Austerity and Romanian Legal Past. In R. Mańko, C. Cercel, A. Sulikowski (Eds.), Law and Critique in Central Europe. Questioning the Past, Resisting the Present. Oxford: Oxford University Press.

Durviete, I., Ozolins, U. (2016). The Latvian referendum on Russian as a second state language. Language Problems and Language Planning 40/2, 121-145.

Gawin, D. (2010). Legitymizacja i pamięć. In A. Rychard, H. Domański (Eds.), Legitymizacja w Polsce. Nieustajacy kryzys w zmieniajacych się warunkach? Warszawa: IFiS PAN.

Gromski, W. (2000). Autonomia i instrumentalny charakter prawa. Wrocław: Kolonia LTD.

Gromski, W. (2018). Akty instrumentalizacji prawa i ich granice. Przeglad Prawa i Administracji 114, 95-106.

Jundza, T. (Ed.). (2000). 4. maijs, Rakstu, atminu un dokumentu krajums per Neatkaribas deklaracju. Riga: Fonds Latvijas Vēsture.

Klymenko, L. (2017). Cutting the Umbilical Cord: The Narrative of the National Past and Future in Ukrainian De-communization Policy. In U. Belavusau, A. Gliszczyńska (Eds.), Law and Memory. Towards Legal Governance of History. Cambridge: Cambridge University Press.

Krygier, M. (2012). Rule of Law. In M. Rosenfeld, A. Sajo (Eds.), The Oxford Handbook of Comparative Constitutional Law. Oxford: Oxford University Press.

Loughlin, M. (2010). What is constitutionalisation? In P. Drobner, M. Loughlin (Eds.), The Twilight of Constitutionalism? Oxford: Oxford University Press.

Marszałek-Kawa, J., Ratke-Majewska A., Wawrzyński, P. (2016). Polityka pamięci i ksztattowanie tożsamości politycznej w czasie tranzycji postautorytarnej. Warszawa: Difin.

Misztal, B. (2003). Theories of Social Remembering. Maidenhead: Open University Press.

Młynarska-Sobaczewska, A. (2013). Normatywizacja tożsamości zbiorowej w preambułach do konstytucji państw postkomunistycznych. Filozofia Publiczna i Edukacja Demokratyczna 2/2, 104-133.

Přibáň, J. (2007). Legal Symbolism: On Law, Time and European Identity. Aldershot: Ashgate.

Rosenfeld, M. (2010). The Identity of the Constitutional Subject. Selfhood, Citizenship, Culture and Community. London-New York: Routledge.

Thornihill, C. (2017). A Sociology of Constitutions. Constitutions and State Legitimacy in HistoricalSociological Perspective. Cambridge: Cambridge University Press.

Wronkowska, S. (2017). Kilka tez o instrumentalizacji prawa i ochronie przed nią. Przegląd Prawa $i$ Administracji 110, 107-112. 